\title{
PRELIMINARY REPORT ON UNIQUE LAMINATED HOLOCENE SEDIMENTS FROM THE QARUN LAKE IN EGYPT
}

\author{
Leszek Marks ${ }^{1}$, Alaa Salem ${ }^{2}$, Fabian Welc ${ }^{3}$, Jerzy Nitychoruk ${ }^{4}$, Zhongyuan Chen $^{5}$, Abdelfattah Zalat ${ }^{6}$, \\ Aleksandra Majecka ${ }^{1}$, Marta Chodyka ${ }^{4}$, Marcin Szymanek ${ }^{1}$, Anna Toloczko-Pasek ${ }^{1}$ \\ ${ }^{1}$ University of Warsaw, Faculty of Geology,Warsaw,Poland, e-mail: leszek.marks@uw.edu.pl, \\ a.majecka@uw.edu.pl,m.szymanek@uw.edu.pl,atoloczko@student.uw.edu.pl \\ ${ }_{3}^{2}$ Kafrelsheikh University, Faculty of Science, Kafrelsheikh, Egypt, e-mail: alaa.salem@sci.kfs.edu.eg \\ ${ }^{3}$ Cardinal Stefan Wyszyński University, Institute of Archaeology,Warsaw, Poland, e-mail: f.welc@uksw.edu.pl \\ ${ }^{4}$ John Paul 2 nd State Higher School, Faculty of Economic and Technical Sciences, Biała Podlaska, Poland, \\ 5e-mail:j.nitychoruk@uw.edu.pl,m.chodyka@dydaktyka.pswbp.pl \\ 5 State Key Laboratory of Estuarine and Coastal Research, East China Normal University, 200062 Shanghai, \\ China,e-mail:z.chen@ecnu.edu.cn \\ ${ }^{6}$ Tanta University, Faculty of Science,Tanta,Egypt, e-mail: abzalat@yahoo.com
}

\begin{abstract}
The Lake Qarun (Faiyum Oasis, northern Egypt) is a relic of the much larger Holocene lake. Past lake levels and extensions were reconstructed, based on setting of archaeological sites scattered along northern paleoshores of the ancient lake. However, geoarcheological works did not yield enough data to establish continuous environmental history of the lake. A deep drilling FA-1 on the southeastern shore of the lake, performed in 2014, supplied with a core, $26 \mathrm{~m}$ long that is the one of the longest lake sediment cores in northeastern Africa. The basal section of the core consisted of thin-laminated diatom marly deposits, underlain at the Late Pleistocene/Holocene boundary by coarse-grained sands. The sediment lamine were quite well developed, especially in the lower part of the core. Preliminary results indicated annually deposited sediment sequence with seasonality signals provided by microlamine of diatoms, calcite, organic matter and clastic material. Early Holocene varved sediments from the Faiyum Oasis supplied with exceptional paleoenvironmental data for northeastern Africa, which enriched a record from previous logs drilled at the southwestern margin of the Qarun Lake.
\end{abstract}

Key words: Holocene, laminated sediments, Qarun Lake, Faiyum Oasis, Egypt.

Manuscript received 14 June 2015, accepted 16 February 2016

\section{INTRODUCTION}

The Faiyum Oasis occupies a natural depression of $12,000 \mathrm{~km}^{2}$, modeled by deflation and denudation during Middle and Late Pleistocene (cf. Ball, 1939; Issawi, 1976). It is separated from the Nile valley by a desert strip running from the north-northeast to the south-southwest, some $25 \mathrm{~km}$ wide and elevated to $160 \mathrm{~m}$ a.s.l. (Embabi, 2004). The depression is connected with the Nile through a passage occupied today by the Bahr Yousef and Hawara Canal that supplies the Faiyum Oasis with freshwater (Fig. 1). A northern boundary of the depression is a questa that separates it from a plateau at $250 \mathrm{~m}$ a.s.l., composed of Middle and Upper Eocene limestones, Oligocene clastics and basalts, overlain in turn by Miocene formations (Beadnell, 1905; Issawi, 1976). In the northern part of the depression, there is a shal- low and saline Qarun Lake (Fig. 2). It is a relic of a vast Holocene reservoir, sediments of which cover most of the bottom of the Faiyum Oasis (Fig. 1).

The main goal of the Nile Change Climate Project (realized in years 2013-2016), financed by the Polish Centre of Science was to perform a deep drilling at the southeastern shore of the Qarun Lake. The full-cored borehole FA-1 was drilled in February 2014 and supplied with a core, representing a complete and undistributed sequence of Holocene lake sediments, $26 \mathrm{~m}$ long (Figs 1, 3). The upper part of the core was completed with the short borehole FA-2. The cores were subjected to detailed laboratory examination, among others including lithological and geochemical analyses (SEM/EDS). Preliminary results enabled correlation of the core FA-1 with the cores QARU 9, 10 and F1-08, collected several years ago by a team of Flower et al. $(2006,2012)$ (Figs 4, 5). Detailed 


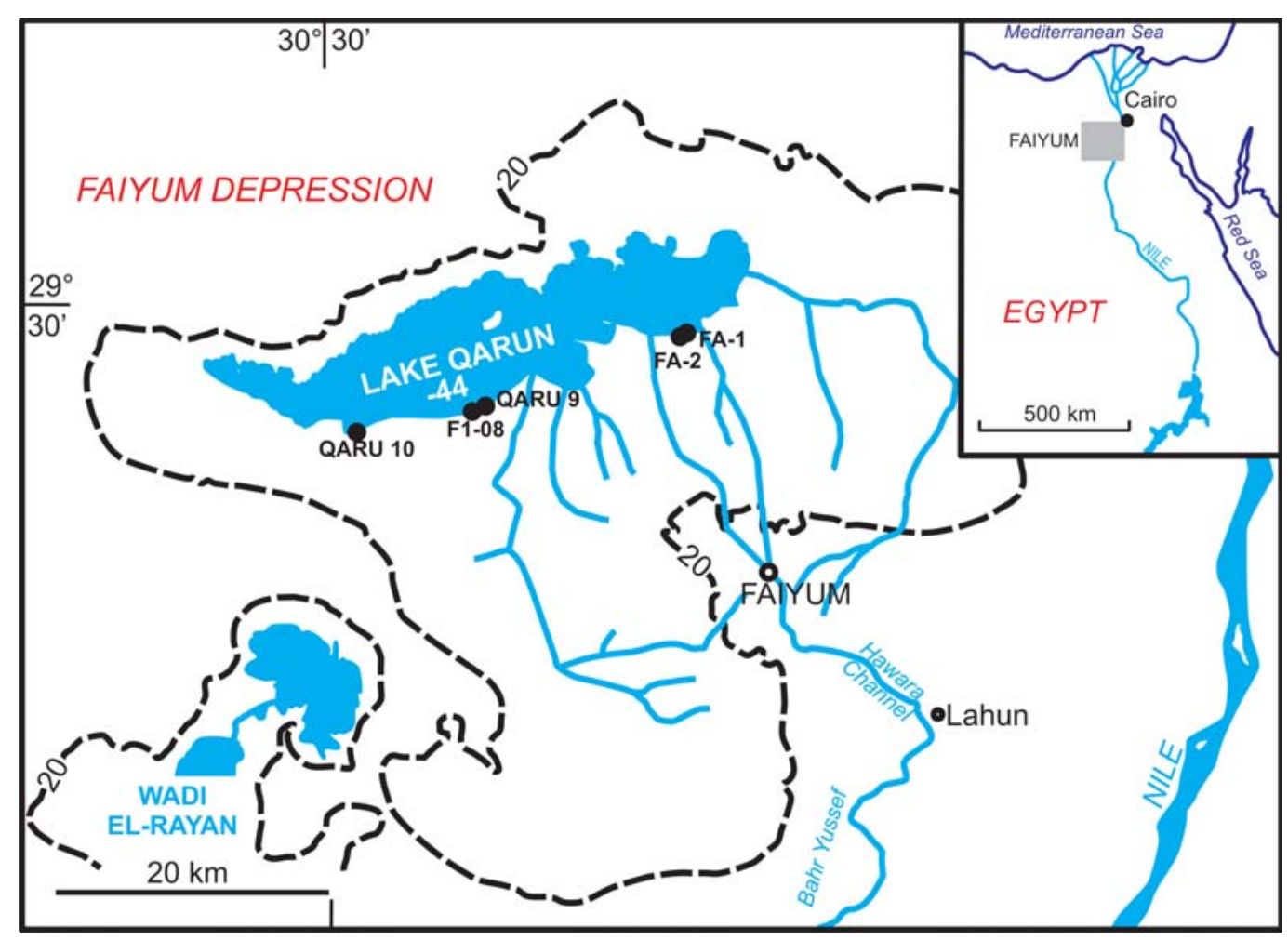

Fig. 1. Sketch plan of the Faiyum Oasis with the modern Qarun Lake in the northern part of the basin; drillings QARU 9, QARU 10, F1-08 and FA-1, FA-2 along the southern margin of the modern Qarun Lake after Flower et al. (2012), modified; the contour line $20 \mathrm{~m}$ a.s.l. demarcates maximum lake level in the Holocene.

analyses will enable complex correlation of the lithologicalsedimentological record of the core FA-1 with available geoarcheological data, making reconstruction of the Holocene climate change possible, not only for Egypt but also for northeastern Africa and in the context of human colonization of this area.

\section{SHORT HISTORY OF THE FAIYUM OASIS LAKE DURING THE HOLOCENE}

The Faiyum Oasis was connected with the Nile presumably already during the Middle Pleistocene during so called the Prenile phase, correlated with Acheulian culture. A large and deep-water reservoir has developed at that time, with water level at 44-46 m a.s.l. and the area of about $2800 \mathrm{~km}^{2}$ (Said 1993). At 400-450 kyrs BP the lake contained over 100 $\mathrm{km}^{3}$ of water (Ball 1939). This episode is indicated by Middle Pleistocene sandy-gravel deposits, recognized in marginal zones of the present Fayum depression (Ball 1939; Said 1993). Starting from the Middle Paleolithic, the lake level has been systematically falling down. At the end of the Pleistocene, a connection between the Faiyum Oasis and the Nile has been practically cut off (Said et al., 1972a, b; Wendorf and Schild, 1976; Embabi, 2004). A renewed connection appeared at about 9,500 yrs BP that is during the early Holocene (Butzer 1998). Injection of the Nile water into the depression was due to reactivation of a summer monsoon in the Ethiopian Highlands. It resulted in increased water inflow and decreased sediment discharge from the Blue Nile to the northern Nile (Woodward et al., 2007). At that time a vast lake, fed with the Nile, developed in central Faiyum Oasis (Wendorf and Schild, 1976). During the early Holocene the lake was $60 \mathrm{~km}$ long and $70 \mathrm{~m}$ deep (Fig. 1). Its reactivation favored development of Epipalaeolithic settlements of the so-called Qarunian culture in the Faiyum area (Caton-Thompson and Gardner, 1934; Wendorf and Schild, 1976; Shirai, 2010).

The present Qarun Lake (ancient Moeris) in the central Faiyum $\left(29,28^{\circ} \mathrm{N}, 30,29^{\circ} \mathrm{E}\right)$ is irregular and elongated westeastwards (about $40 \mathrm{~km}$ ), being a small relic of the early Holocene reservoir (cf. Caton-Thompson and Gardner, 1934; Wendorf and Schild, 1976; Hassan, 1986; Hassan and Hamdan, 2008) (Fig. 1). It is still the largest saline lake in the Western Desert of Egypt, Sudan and Libya. A mean depth of the Qarun Lake is $8.5 \mathrm{~m}$ (El Wakeel, 1963, Flower et al., 2006; El-Shabrawy and Daumont, 2009) and the lake level occurs at 43-44 m b.s.1. (El Sayed and Guindy, 1999; Flower et al., 2013). Due to numerous natural and anthropogenic processes it is a hyper saline reservoir (salinity $>30 \mathrm{~g} / 1$ ), without surface outflow and it occupies an area of $235 \mathrm{~km}^{2}$ (Flower et al.; 2006; El-Shabrawy and Daumont; 2009). Water temperature is varied seasonally between 15 and $33^{\circ} \mathrm{C}$ (Ball, 1939; El-Shabrawy and Daumont, 2009; cf. also El-Sayed and Guindy, 1999). Similarly as almost the whole area of Egypt, the Qarun Lake occurs in a zone with a very low precipitation, less than $10 \mathrm{~mm}$ a year (Soliman, 1990).

Considerable changes in extent and depth of the lake in historical time resulted mainly from seasonal inflows from the Nile (Butzer, 1976). The depression was connected with the river with an artificial channel already during the Pha- 


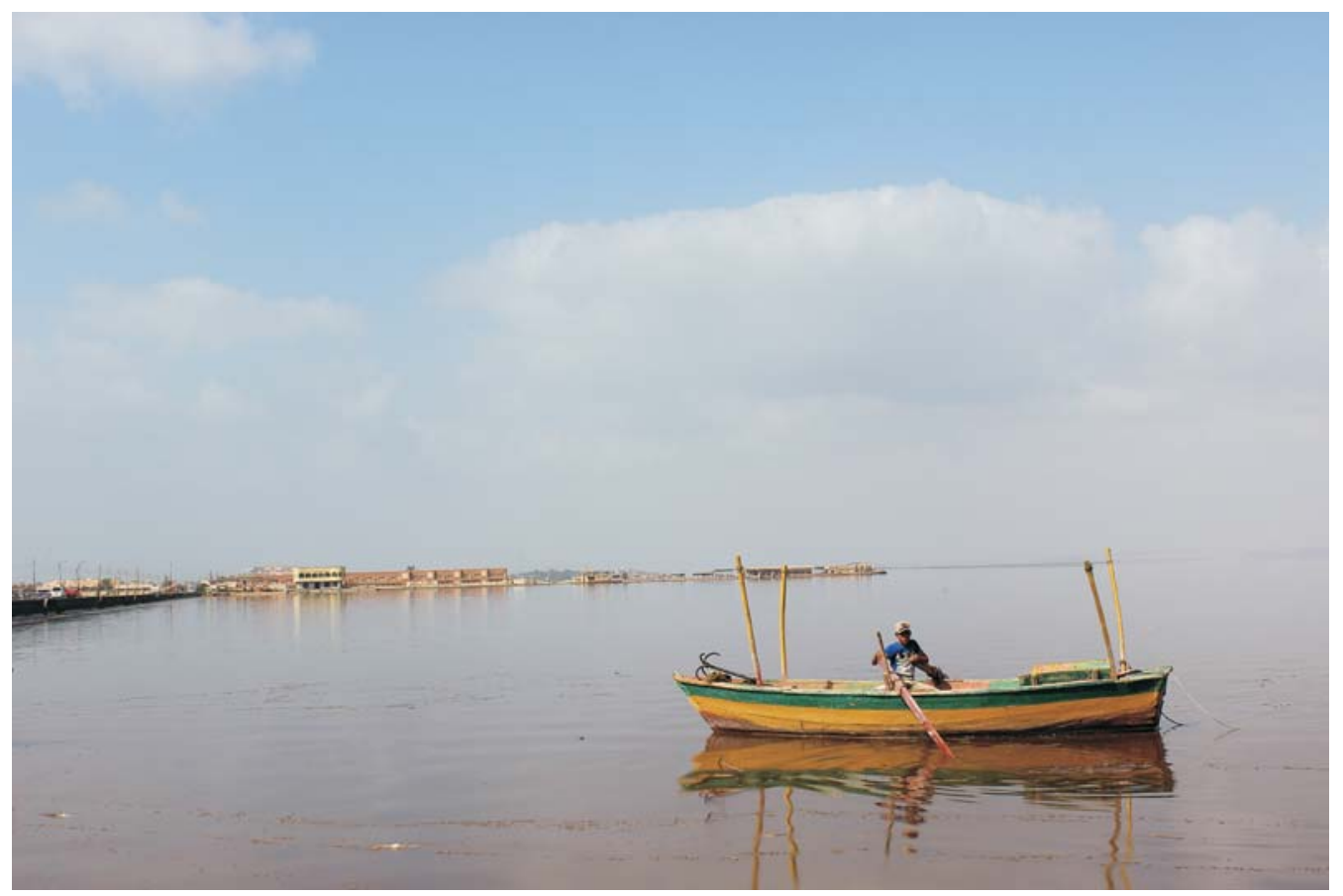

Fig. 2. Southern part of the Qarun Lake; view from the south-east.

raonic time, most probably during the Middle Kingdom (cf. Butzer, 1973). Such connection considerably influenced not only lake chemistry but also its water budget.

Starting from the beginning of the 20th century, a history of the Qarun Lake has been intensively studied, particularly its shores with abundant archaeological sites. Previous investigations were focused mainly on examination of terrestrial exposures with non-laminated diatomite in northeastern Faiyum Oasis (cf. Aleem, 1958; Wendorf and Schild, 1976; Przybyłowska-Lange, 1976; Flower et al., 2013) where several Neolithic archaeological sites were identified (cf., Caton-Thompson and Gardner, 1929; Wendorf and Schild, 1976; Shirai, 2010). Some of them were located along the previous shoreline of the Holocene lake what enabled multidisciplinary geoarchaeological investigations in the early 20th century (cf. Caton-Thompson and Gardner, 1929; Sandford and Arkell, 1929 and Said, 1962 and Said et al., 1972b; Wendorf and Schild, 1976; Mehringer et al., 1979; Hassan, 1986, Baioumy et al., 2010; Hassan et al., 2011). They resulted not only in reconstruction of colonization phases in the Faiyum Oasis during the prehistoric and pre-dynastic time, but enabled also determination of successive phases of lake development, particularly of its coastlines and identification of several transgressive-regressive episodes (cf. especially Issawi, 1976; Wendorf and Schild, 1976; Hassan et al., 2011).

There is no doubt that a high lake water level and large extent of the lake during the early Holocene resulted from the high Nile flood discharge (Hassan et al., 2012). Three aggradation phases were previously distinguished in the early Holocene and determined as Arkin, El Kab and Catfish. They correspond generally with subsequent high lake level phases named Paleomoeris, Premoeris and Protomoeris (cf. Kobusiewicz, 1976; Wendorf and Schild, 1976; Hassan,
1984; Kozłowski and Ginter, 1993). The last aggradation named Arkin, occurred probably during Early Dynastic and Old Kingdom periods (4600-4200 yrs BP; (Kozłowski and Ginter, 1993). However, as it is indicated by Wendorf et al. (1986) in Wadi Kubbaniya, correlation of aggradation phases with high levels of the Nile seems doubtful from a point of view of hydrodynamics of sedimentary processes. Competence of the Nile was reduced during arid periods in northeastern Africa but in the same time, river capacity and sediment load could have considerably increased, resulting in a quick rise in channels and floodplains (the so-called aggradation phase). In contrast, wet phases were indicated by increased water discharge in the Nile catchment area, because of slope stabilization due to dense vegetation cover. In consequence, the sediment load was reduced and down-cutting processes initiated (the so-called regressive phase). These recent investigations proved univocally that the Nile and its floods played a key role for water level changes in the lake during the Holocene.

It should be emphasized that many methodological and terminological inconsistencies in previous studies and researches meant that the question of aggradation and downcutting episodes and climatostratigraphic reconstructions concerning the Nile basin in the Late Pleistocene and Holocene must be examined again. The authors find it to be one of the most important future challenges for paleoclimatology and geoarchaeology in northeastern Africa.

\section{METHODS}

Sedimentary sequences from the earlier cores QARU 9, 10 and F1-08 (Flower et al.. 2012), due to their close location to one another in central and western part of the Qarun Lake (Fig. 1), do not represent complete hydrodynamics and 


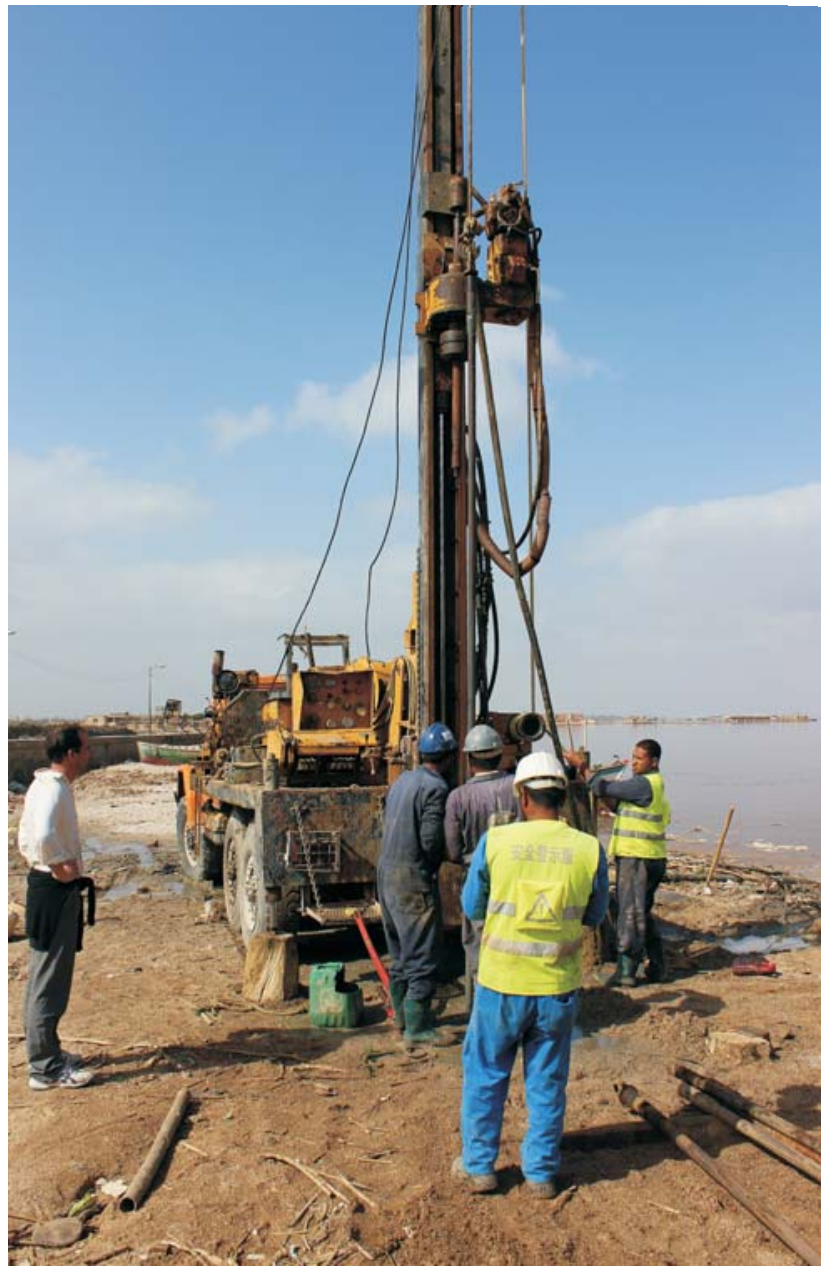

Fig. 3. Drilling FA-1 core in southern margin of the Qarun Lake, using a drilling rig of the Acer company.

paleogeography of the lake that has been located in the central part of the Faiyum depression during the Holocene. This hiatus was filled with the core FA-1, which was supplemented with a shallow borehole (FA-2, depth $4 \mathrm{~m}$ ) located in a close vicinity in the eastern part of the southern shore of the Qarun Lake (location: $29^{\circ} 26^{\prime} 36^{\prime \prime}-29^{\circ} 31^{\prime} 15^{\prime \prime} \mathrm{N}, 30^{\circ} 23^{\prime} 52^{\prime \prime}$ $30^{\circ} 49^{\prime} 55^{\prime \prime}$ E, elevation: 44 b.s.l.) (Fig. 1). Together with above mentioned logs, FA-1 core represents one of the longest and the most complete sequences of the Holocene lake sediments in northeastern Africa (see also long cores obtained during extensive program realized by Stanley et al., 1996, in the northern Nile Delta).

Drilling works were done with a self-propelled American set Acer (Fig. 3). Research material was collected with a use of plastic pipes, $1 \mathrm{~m}$ long and $10 \mathrm{~cm}$ in diameter. Every core reach was described in detail and sampling was done in laboratory at every $5 \mathrm{~cm}$ interval. Preliminary lithological description was based on macroscopic inspection, supplemented with detailed examination of selected fragments of the core with a use of electron microscope Hitachi TM 3000 SEM, combined with microprobe EDS. The main aim was a general lithological-geochemical analysis of the sediments, enabling a selection of samples to other specialist examination and analyses.

\section{PREVIOUS RESEARCH}

Several full-cored and quite deep boreholes were drilled at the southern shore of the Qarun Lake during the last few years (Fig. 1) and were subjected to specialist analyses, particularly to diatom examination (cf. Keatings et al., 2010; Flower et al., 2012, 2013; Hassan et al., 2012). The most complete and the longest $(21.4 \mathrm{~m})$ sediment sequence was collected from the borehole QARU 9, drilled in the central part of the southern lake shore (Flower et al., 2013) (Fig. 1). The recorded lake sequence started with grey coarse-grained sand with pebbles at depth $20.8 \mathrm{~m}$. From depth $17.3 \mathrm{~m}$ there were olive-grey silty clay, interbedded with white, $1 \mathrm{~mm}$ thick lamine of diatomite and carbonates. From the depth $10.95 \mathrm{~m}$ there were white coarse-laminated sediments and the upper part of the sequence was composed of sand and dark brown to grey silty clay (Flower et al., 2013). The section of the borehole F1-08, $20.3 \mathrm{~m}$ long and located nearby, looks very similar (Fig. 4). Three radiocarbon ages from a basal part of the core determined a beginning of the early Holocene lake development to about 10 kyrs BP (Flower et al. 2012). The shortest of these three cores, labeled as QARU 10 (length: $10.4 \mathrm{~m}$ ), was located also at a southern shore of the present Qarun Lake but $14 \mathrm{~km}$ to the west from the other two (Fig. 1). This core indicated a different lithology (Flower et al., 2013).

In basal fragments of all these three cores (QARU 9, QARU 10 and F1-08) there was the Late Pleistocene coarse sand, overlain by characteristic fine-laminated silty clay, from $1 \mathrm{~m}$ (QARU 10) to almost $3 \mathrm{~m}$ (QARU 9) thick. Above these thin-laminated series, the sediments indicated more irregular and thicker $(>1 \mathrm{~cm})$ lamination. Starting from the depth of $10.85 \mathrm{~m}$ (QARU 9), 13.8 (F1-08) and $4.7 \mathrm{~m}$ (QARU $10)$, there were mostly massive silty clays and clays. The uppermost parts of these three cores were composed by sands of varying thickness (Flower et al., 2013).

The Holocene sedimentary sections of the QARU 9, QARU 10 and F1-08 cores comprised a unique environmental record of the Qarun Lake history. They represented sedimentological structure of the southern part of the lake that has not been previously systematically investigated as the northern part had. It is very important also that the lake sediments were partly laminated and therefore supplied with high-resolution paleoclimatic data (Fig. 6).

A $1.78 \mathrm{~m}$ long sequence of fine-laminated lacustrine sediments of the core QARU 9 was particularly important for paleoenvironmental and paleohydrological reconstruction. A laminated part of this core was composed of cyclothems with 1-mm thick lamine that, as indicated by SEM examination, were composed of calcite (micrite), detrital quartz and feldspar grains (about 0.1-0.2 $\mathrm{mm}$ in diameter), diatomite, amorphic organic matter and interbeds of clayey detrital material. The core QARU 10 revealed a typical multilayer structure of the thin laminated section with diatoms located between layers of angular silt grains and of calcite, often intermixed with characteristic brown amorphous material, taken as to be the organic matter (Flower et al., 2012). The terrigenous material within the clayey laminated series seems to have been delivered to the reservoir during the Nile floods at the end of summer when the water stagnated after 


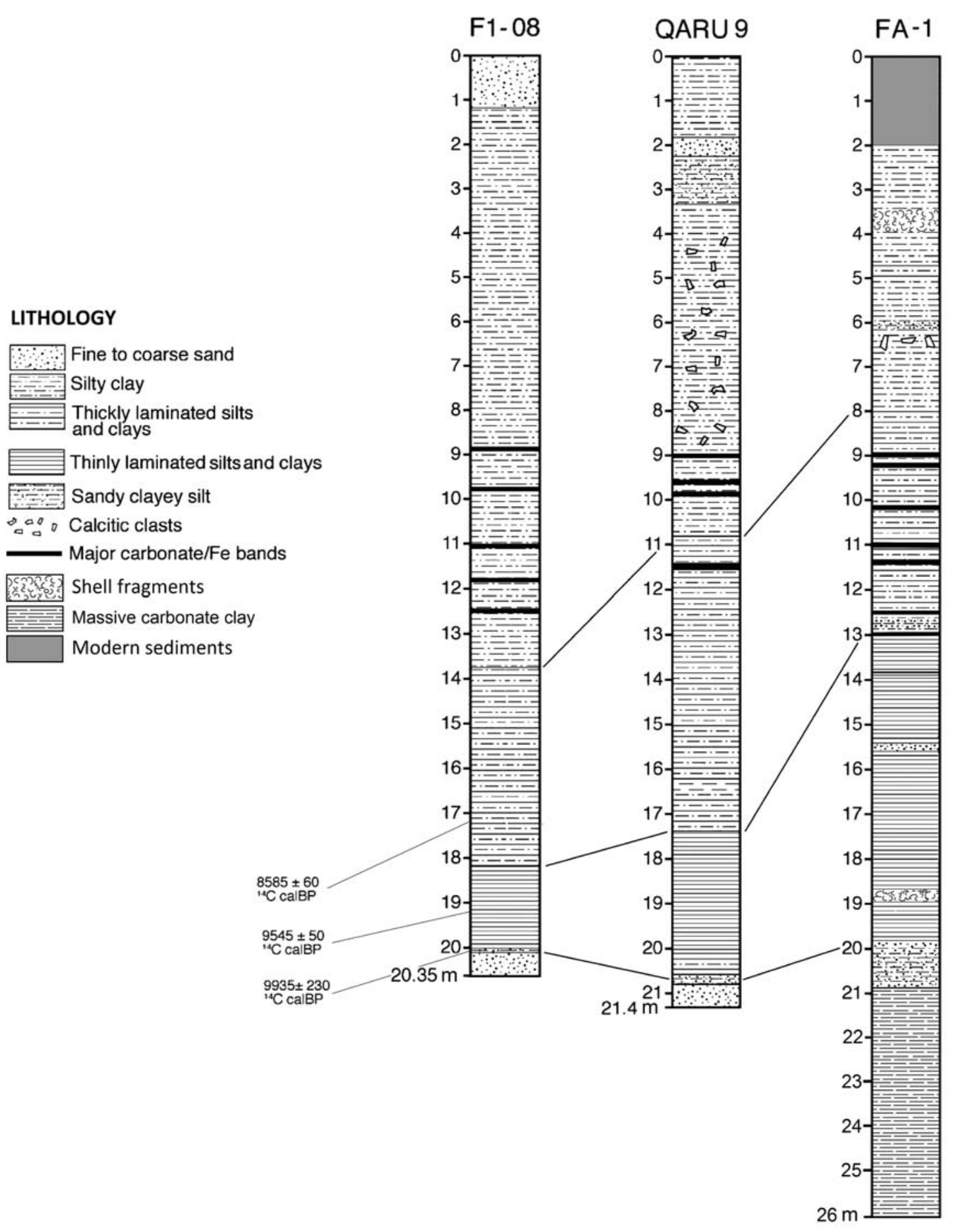

Fig. 4. Logs of the drillings QARU 9, F1-08 and QARU 10 after Flower et al. (2012) and with a log of the drilling FA-1; for their location see Fig. 1.

reaching its highest level. Flower et al. (2012) stated that timing of clastic deposition events could be also connected with a local winter rainfall regime. From the other side, calcite precipitation seems clearly to have been a summer phenomenon that usually occurred when water temperature and $\mathrm{pH}$ increased significantly, possibly because of non-diatom plankton growth. In effect, the calcite layers were essentially free of detrital clastics, indicating a lack of runoff during summer. In turn, interbeds of amorphic organic matter that were con- centrated between diatomite lamine and layers of biogenic calcite, could indicate predominance of internal lake biological processes, including high algal productivity. Finally, the same researchers attributed fine-laminated sections of the cores QARU 9, QARU 10 and F1-08 to seasonal cycles of sediment deposition. Well preserved diatoms in these sections, together with carbonate and terrigenous signal peaks demonstrated clearly that the core parts with thin lamination, dated to the early Holocene, were in fact classical varves 


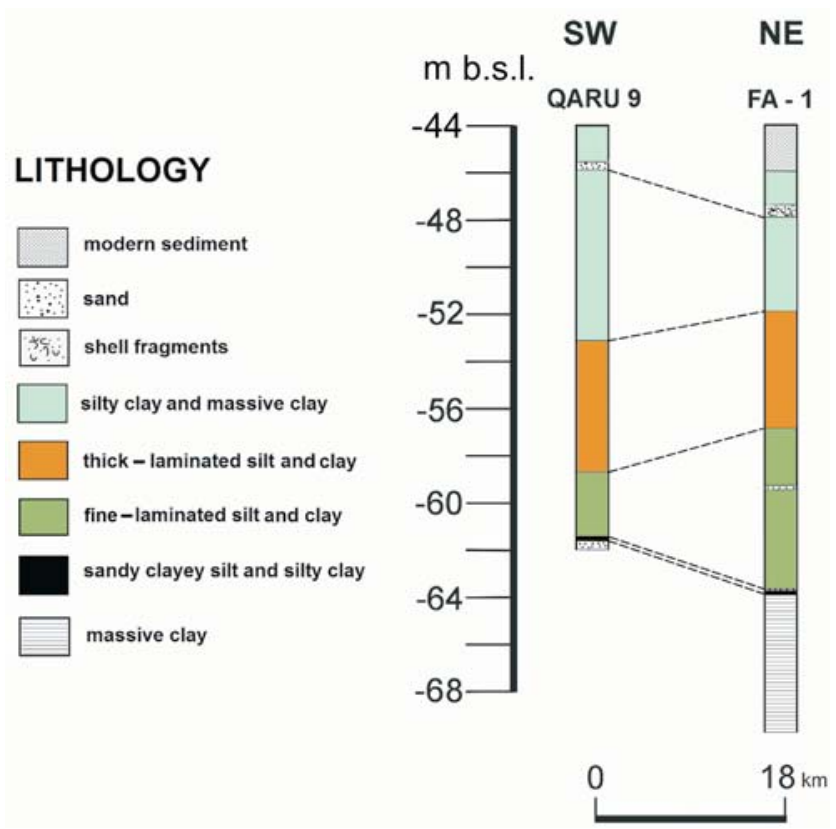

Fig. 5. Simplified cross-section of lake sediments in the Faiyum Oasis between the boreholes QARU 9 after Flower et al. (2012) and FA-1.

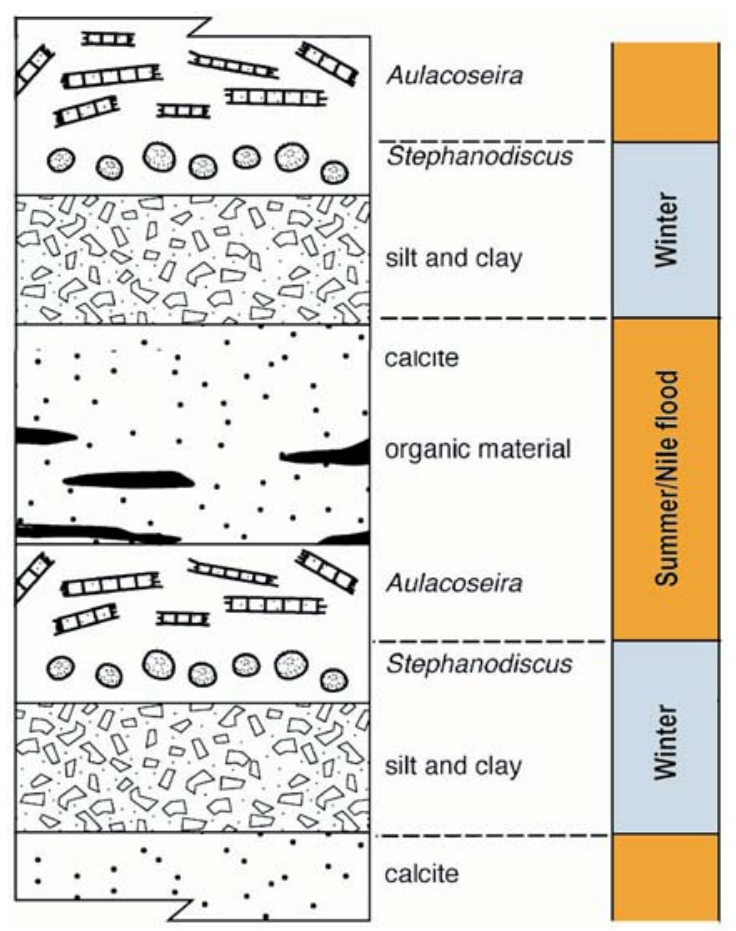

Fig. 6. Model of annual deposition recorded in thinly laminated sections of the sediment of the cores QARU 9 and FA-1; adopted after Flower et al. (2012), modified.

(Flower et al., 2012, on definition of classical varves cf. Zolitschka et al., 2015) (Fig. 6).

From the point of view of deposition of fine-laminated sequences, it does seem important that in diatomite layers there was either the species Aulacoseira granulata (Simonsen, 1979) or Stephanodiscus sp. (Flower et al., 2013) or both. The layers with the predominant Stephanodiscus were usually preceded by laminas with Aulacoseira and it could be connected with inter-annual water circulation, depth and nutrients in the lake (Kilham et al., 1986; Flower et al., 2013). In fact, Aulacoseria granulata is a common species in the present Nile (Talling et al., 2009). Blooms caused by these algae start in late August or in September and are connected with initial flooding that presumably has occurred also in the early Holocene (Flower et al., 2012). From the other side, Stephanodiscus is absent in the present Nile but it was abundant in Holocene deposits of the large East African lakes (Gasse et al., 1987; Flower et al., 2013). The species of Stephanodiscus recorded in the Faiyum cores have been previously described as African endemics, developed within a lake rather than representing populations brought northwards into the lake by the Nile floods (Flower et al., 2013). Another abundant species in thinlyeated sections of the cores QARU 9 and QARU 10, was Stephanodiscus galileensis, which was attested in the Holocene sediments of the Lake Kinneret in Israel (Hakansson and Erhlich, 1987). It should be noted that S. aegyptiacus (Ehrenberg, 1845), found also in the Faiyum sediment cores, is an extinct species that also occurred in the Atlantic trade winds area but the latter did not substantiate its occurrence in the North African region (Flower et al. 2013). According to the same authors, the origin of the diatom species attested in the Lake Qarun sediments seems uncertain. It is however clear that the Stephanodiscus assemblage of the early Holocene deep lake phase developed and declined rapidly (Flower et al., 2012).

Analysis of varvograms for the core QARU 9 enabled also determination of the annual sedimentation rate for 1.1$1.5 \mathrm{~mm}$ during the early Holocene lake. Thickness of diatom lamine must have been dependent on intensity of algae flowering during successive years. Thin-laminated sediment sections in the cores QARU 9, QARU 10 and F1-08 are gradually thinner westwards what is presumably due to dipping of the basin bedrock westwards. Therefore, varied relief of the pre-Quaternary bedrock has been a principal factor that modeled not only the basin of the Holocene lake but also its hydrological-sedimentary characteristic (Flower et al., 2012).

In summary, three described above sediment cores (QARU 9, QARU 10 and F1-08) from the southern shore of the modern Qarun Lake indicated broadly similar sedimentary changes that were generally compatible with progressive drop of the lake level during middle and late Holocene. The youngest development phase of the lake is represented by structure-less silty clay with low diatom abundances, occasional calcite clasts and several thick bands of Fe and Ca minerals. Until a secure chronology is developed for the described Holocene cores from the Qarun Lake, a precise timing of major environmental changes remains elusive (Flower et al., 2013).

\section{LITHOLOGY OF THE CORE FA-1}

From a lithological point of view, the log of FA- 1 is similar to the cores QARU 9, QARU 10 and F1-08 (Figs 1,4). All this sections represent comparable records of main phases of lake evolution during the Holocene (Fig. 4). A beginning of the early Holocene sequence is indicated by coarse sand, oc- 
curring at the following depths: $21.4 \mathrm{~m}$ (QARU 9), $20.35 \mathrm{~m}$ (F1-08), $10.4 \mathrm{~m}$ (QARU 10) and $21.0 \mathrm{~m}$ (FA-1). Characteristic thin-laminated sediments resembling typical varves overlie it. Such basic change of deposition from sandy-clayey to silty one indicates firstly a climate change in the Nile drainage basin but also stabilization of the direct hydrological connection between the Faiyum Oasis and the Nile valley already in the early Holocene, what was already suggested among others by Butzer (1998). The characteristic layer composed of sand and silt corresponds roughly to the boundary Pleistocene/Holocene what is supported by radiocarbon dating of the lower part of the core F1-08, which is $9935 \pm 230$ cal yrs BP (cf. Flower et al., 2012) (Fig. 4). A beginning of the lake in the Faiyum Oasis could be therefore estimated at about 10,000 yrs BP that is during a basic climate change, expressed by humidification in the whole catchment of the Nile, initiated at the beginning of the Holocene (cf. Butzer, 1998).

Based on these four cores, paleogeography of the Holocene lake in the Faiyum Oasis can be reconstructed. The thickest early Holocene series of regularly laminated clayey silt of the core FA-1 and its setting against all the other boreholes suggests that the lake was deepest in its northwestern part of the present Fayum depression and the deposition rate was the largest there. A top of Paleogene and Neogene rocks raises westwards what results in considerable change of the reservoir bathymetry, making it shallower. It indicates also that the main water influx to the reservoir entered the depression from the southeast. The latter confirms a key role of the Hawara Gap that separates a rock massif from the Nile valley (Figs 1, 5).

In the logs QARU 9 and F1-08 the laminated series are similarly thick (2.50 $\mathrm{m}$ and $1.80 \mathrm{~m}$ respectively). In the log FA-1 these sediments are thicker, reaching $6.20 \mathrm{~m}$. A lamination is composed of white diatomite, carbonate, organic and terrigenous (composed of clay) layers. Such lamination reflects most probably annual sedimentary cycles, as it was already suggested by Flower et al. (2012). Fragment of the core F1-08, dated to the early Holocene, contains 11-12 pairs of dark-light lamine in $1 \mathrm{~cm}$ thickness. Much less lamina pairs (6-7) are recorded in the cores QARU 9 and FA-1. In both cases there are also very thin $(0.5 \mathrm{~mm})$ layers of amorphic organic matter deposited presumably due to settling of the sediment that was either supplied to the lake during floods of the Nile or they were the effect of internal biogenic production. On the other hand, considerably thicker series of laminated deposits in the core FA-1 than in the other two that is QARU 9 and F1-08 (Fig. 4), could be caused by close occurrence of hydrological connections between the lake and the Nile and also by local, specific environmental and climatic conditions.

It should be noted here, that phytoplankton development in most contemporary lakes in Africa, located in a zone of every year migration of Inter-tropical Convergence Zone (ITCZ) is mostly stimulated by occurrence of winter rainfall season and summer dry period. This seasonal change is expressed in lake cores by deposition of dark lamine that correspond to sedimentation of terrigenous material supplied to the reservoir during rainy seasons and is correlated with relatively low diatom productivity (Pilskaln and Johnson, 1991). In case of the Faiyum Oasis, there is no evidence this area was in range of summer belt rains during any part of the Holocene. What is more, the newest palaeoclimatic reconstructions suggest that ITCZ did not reach the Faiyum Oasis, even during the wettest phases of the early Holocene (Haynes, 2001; Kuper and Kröpelin, 2006; McCorriston, 2006; Phillips et al., 2012). The monsoon season was expressed there indirectly by annual inundation, disposition of the Nile sediments and fluctuations of the lake levels filled depression. Occurrence of dark lamine composed almost of terrigenic material is very significant, therefore other factors as strong influence of northern circulation (winter rains) should be also considered. Some scholars already suggested that the Faiyum Oasis was presumably in uenced by a southward movement of Mediterranean winter circulation (winter rains) during early to middle Holocene than the position of the ITCZ or the Nile ?ood fluctuations (Hassan et al., 2001; Arz et al., 2003; Kindermann et al., 2006; Shirai, 2010; Phillips et al., 2012).

The spectral analysis EDS of the samples from the laminated fragment of the core FA-1 (Fig. 4), indicates that contents of individual elements is correlated with macroscopic observations. In the spectrum, there are among others peaks of C, Ca, O, Si, S and Fe. Presence of O, C and Ca should be connected with occurrence of carbonates and mollusc shell fragments in the sediment. Carbon is a component of carbonates such as $\mathrm{CaCO}_{3}$ and interbeds of organic matter, occurring both in the lower and in the upper part of the core FA-1. $\mathrm{Si}$ is the main component of silica $\left(\mathrm{SiO}_{2}\right)$, both of diatom frustules as well as quartz grains dispersed in the sediment. Maximum contents of $\mathrm{Fe}$ and $\mathrm{S}$ indicate presence of pyrite $\left(\mathrm{FeS}_{2}\right)$ that can be also macroscopically observed. Increasing content of other elements as $\mathrm{Al}$ indicates in turn a more intensive influx of terrigenous material into the lake, accompanied by numerous sandy interbeds of varying thickness resulting from sudden supply of allochthonous material due to heavy rainfalls in the region of Faiyum. The latter must have activated a local hydrological system of numerous wadis.

Microscopic (SEM) and macroscopic analyses indicated that a thinly and thickly laminated fragment of the core FA-1 (depth 20-8 m) is composed of greenish-grey limy-clayey silt with small admixture of quartz grains of fine-grained sand (Figs 7, 8). Light lamine contain almost exclusively planktonic diatoms and correspond to periodical phytoplankton blooms. They are composed mostly of diatoms of the genera Stephanodiscus and Aulacoseira that constitute $60-90 \%$ of the phytoplankton mass (Figs 9, 10). As it was mentioned, Aulacoseira is a perfect paleoenvironmental indicator of eutrophic conditions, turbulence, high nutrient and waters rich in silica. These algae can indicate also bathymetric changes in the reservoir (Kilham, 1990). The noted coexistence of Aulacoseira and Stephanodiscus in the described cores results presumably from contents of dissolved silica in lake water. More silica is connected with more Aulacoseira in plankton (Hecky and Kling, 1987; Kilham, 1990; Pilskaln and Johnson, 1991). On the other hand, Stephanodiscus is adjusted to environmental conditions, using reservoir resources as they become available, even in a case when there is a very low concentration of silica in water for a long time (Kilham, 1971, 1990; Tilman et al., 1982; Pilskaln and Johnson, 1991). As Flower et al. (2012) suggested, thin diatomite 


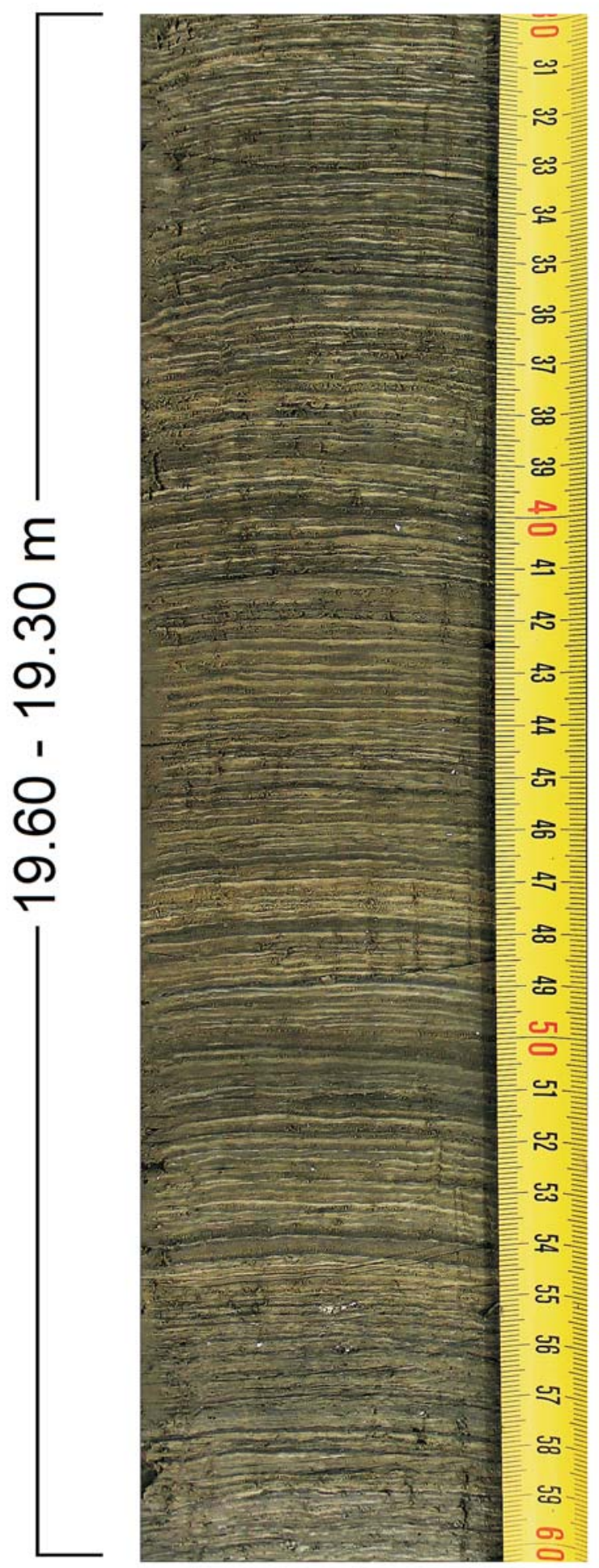

Fig. 7. Fragment of the core FA-1: early Holocene thin-laminated sediments at depth 19.3-19.6 m.

layers rich in Aulacoseria species should be connected with seasonal blooms of this diatom, especially during late summer, when the annual Nile flood reached the Faiyum depression, which was during the first part of Holocene connected hydrologically with the river. On the other hand, the layers with dominant Stephanodiscus should be connected with periods of changing water chemistry, probably during winter or

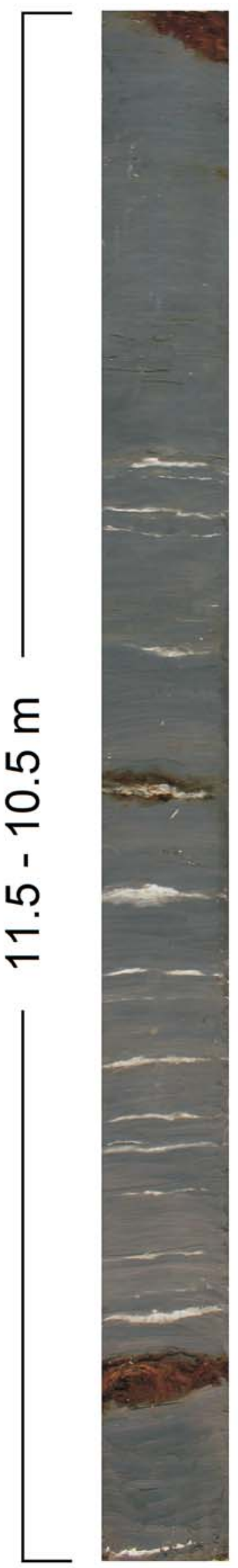

Fig. 8. Fragment of the core FA-1 late-middle Holocene irregularly, thick-laminated sediments at depth $10.5-11.5 \mathrm{~m}$. 


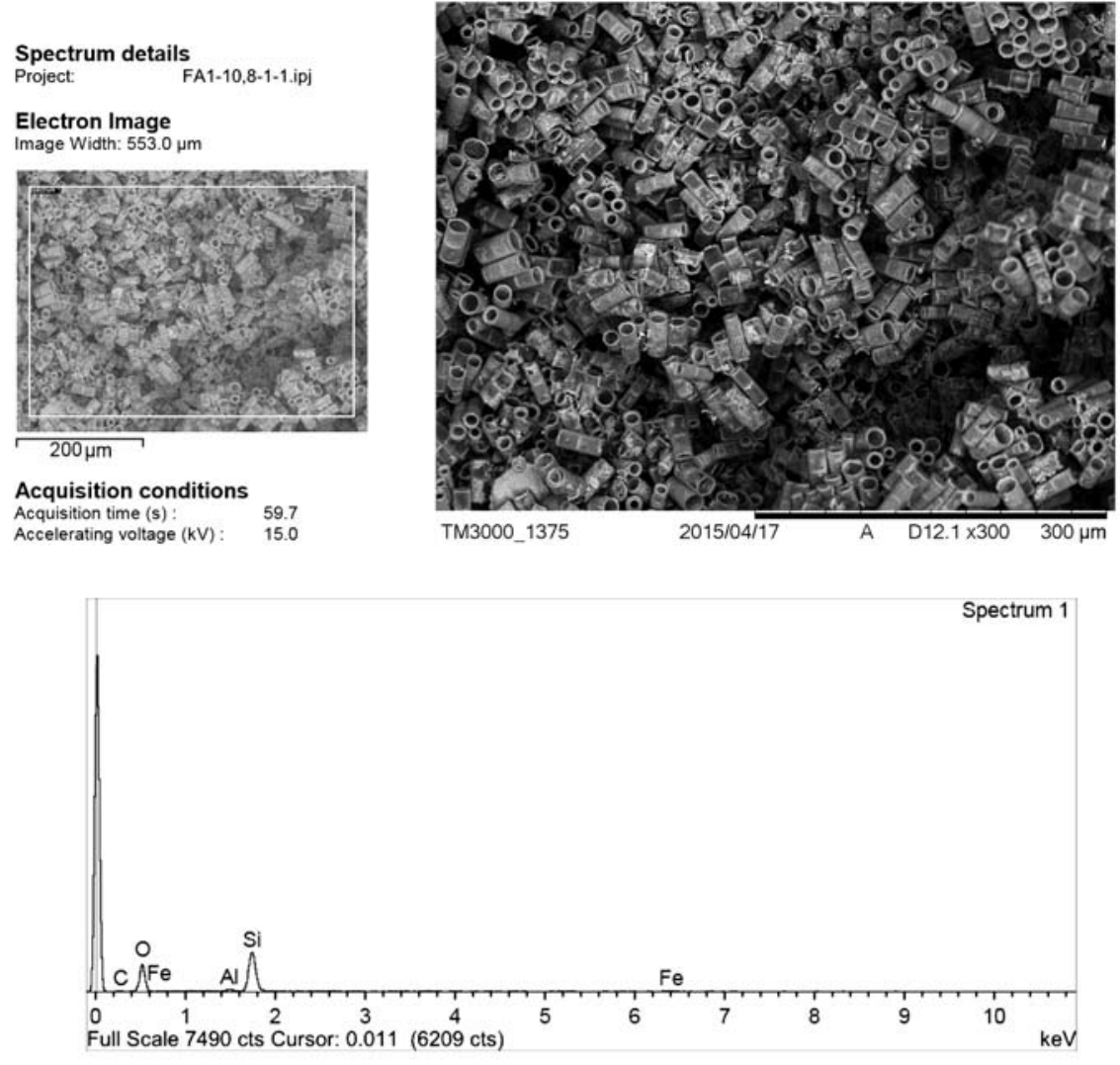

\begin{tabular}{|c|c|c|c|}
\hline \multicolumn{4}{|c|}{ Quantification Settings } \\
\hline Summa & results & & \\
\hline Element & Weight \% & Weight $\% \sigma$ & Atomic \% \\
\hline Carbon & 5.627 & 1.434 & 8.735 \\
\hline Oxygen & 59.412 & 1.244 & 69.242 \\
\hline Aluminum & 1.153 & 0.189 & 0.796 \\
\hline Silicon & 30.115 & 0.827 & 19.993 \\
\hline Iron & 3.694 & 0.576 & 1.233 \\
\hline
\end{tabular}

Fig. 9. SEM/EDS picture and geochemical characteristics (percentage contents of basic chemical elements) in late-middle Holocene sediments at depth $10.8 \mathrm{~m}$ in the core FA-1 (diatom layer with abundant Aulacoseria sp.).

spring, ceased by strong influence of a cold atmospheric circulation from the north.

\section{CONCLUSIONS}

The core FA-1 represents so far longest sequence of Late Pleistocene and Holocene lake deposits in the Faiyum Oasis but also one of the longest in the whole northeastern Africa. Its significance is increased by the fact that the borehole was drilled at a southern shore of the Qarun Lake that is the area that has not been previously investigated in such a detail as its northern and southwestern part. The latter area was examined by long boreholes QARU 9, QUARU 10 and F1-08 that presented a unique record of the environmental history of the lake (cf. Flower et al., 2012, 2013). However, due to their location they did not reflect full image of dynamics and paleogeography of the lake. This gap was filled up partly by examination of the core FA-1.

Sedimentological sequences recorded in all mentioned boreholes (FA-1, QARU 9, F1-08 and QARU 10) contained fine-laminated deposits in their lower parts (varves or rhythmites), therefore they constitute a unique and high-resolution record of paleoclimatic data for the early and middle Holocene in northeastern Africa. The log of the borehole FA-1 is considerably similar in its lithology and structure to the logs of the boreholes QARU 9 and F1-08, and they all reflect similar record of successive phases of lake development. The first, early Holocene phase, deposits of which start at depth $20 \mathrm{~m}$, comprises a deep lake with rich organic life. It is reflected by a series of fine-laminated sediments (rhythmites). Because the Faiyum Oasis was outside a direct influence of a summer monsoon during the Holocene (see above), the monsoon influence could be recorded in fluvial deposits only. They were transported into the depression during summer floods of the Nile (fine-laminated deposits in the lower part of the core FA-1).

There is considerable change in lithology at depth $13.05 \mathrm{~m}$, corresponding to about $6 \mathrm{ka} \mathrm{BP}$ in the middle Holocene. Rhythmites are replaced by sediments with irregular, thick diatomite interbeds, the lake got gradually smaller and shallower 

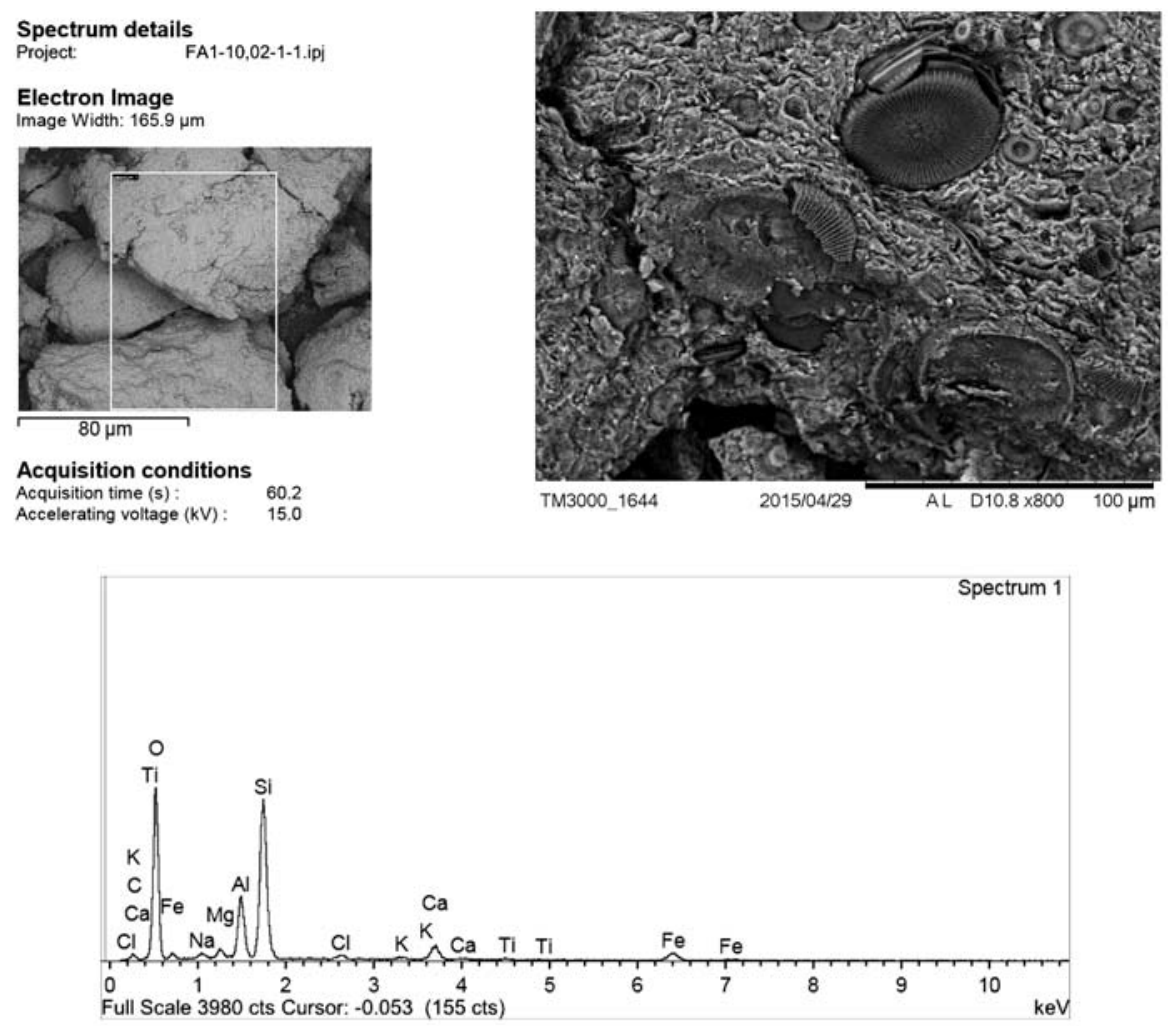

\section{Quantification Settings}

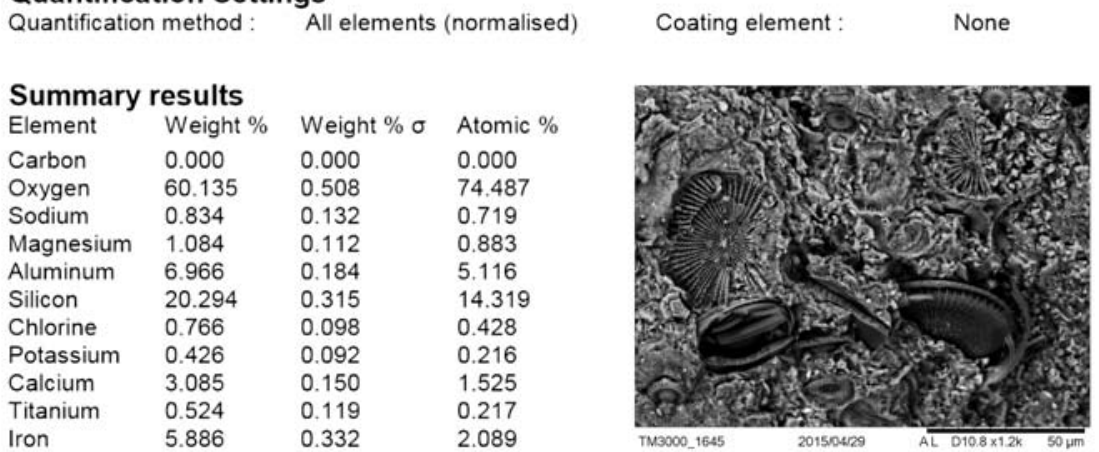

Fig. 10. SEM/EDS picture and geochemical characteristics (percentage conmtents of basic chemical elements) in the late-middle Holocene sediments at depth $10.02 \mathrm{~m}$ in the core FA-1 (diatom layer with abundant Stephanodiscus sp.).

due to progressive aridification, reflected among others by characteristic ferruginous and carbonate interbeds. Nevertheless, the lake remained relatively deep and rich in life. Starting from the depth 6.8 m upwards (late Holocene) a principal change of environmental conditions and deposition occurred, resulting from a progressive climate change, not only in the Faiyum Oasis but also in the whole catchment of the Nile. Increased clay content indicates intensive erosion. The upper part of the section reflects continuation of this process, lasting until the present.

Finally, based on lithology and sedimentological characteristics of the core FA-1, the lake in the Faiyum Oasis seems to have been quite deep and rich in organic life during the early Holocene. During the middle Holocene (probably about $6 \mathrm{ka} \mathrm{BP}$ ), the reservoir has been gradually reduced in size and got shallower as indicated among others by ferruginous interbeds and layers rich in carbonates and with thick diatom lamine (cf. Baioumy et al., 2010; Yamada et al., 2011). According to Hassan (1986), the recognized desiccation episodes were broken down by numerous periods with intensive deposition of fluvial sediments brought by the Nile into the Faiyum Oasis.

\section{Acknowledgements}

The project funded by the National Science Centre in Poland: (decision no. DEC-2012/05/B/ST10/00558). The authors are grateful to the Centre of Mediterranean Archaeology of the University in Warsaw and particularly to Dr. Zbigniew Szafrański for a logistic support during fieldworks in Egypt.

\section{REFERENCES}

Aleem, A.A., 1958. A taxonomic and palaeoecological investigation of the diatom ora of the extinct Faiyum Lake (Upper 
Egypt). University of Alexandria Bulletin 2, 217-44.

Arz, H.W., Lamy, F., Patzold, J., Muller, P.J., Prins, M., 2003. Mediterranean moisture source for an Early-Holocene humid period in the northern Red Sea. Science 300, 118-121.

Baioumy, H., Kayanne, H., Tada, R., 2010. Reconstruction of lake-level and climate changes in Lake Qarun, Egypt, during the last 7000 years. Journal of Great Lakes Research 36, 318-327.

Ball, J., 1939. A contribution to the Geography of Egypt. Survey and Mines Department. Cairo, 339 pp.

Beadnell, H.J.L., 1905. The topography and geology of Faiyum Province of Egypt. Survey Department, Egypt, 88 pp.

Butzer, K.W., 1973. Bahr Yussuf. Lexikon der Ägyptologie 1, 602 pp.

Butzer, K.W., 1976. Early hydraulic civilization, a study in cultural ecology. Chicago-London.

Butzer, K.W., 1998. Late Quaternary problems of the Egyptian Nile: stratigraphy, environments, prehistory. Paleorient 23, 151-173.

Caton-Thompson, G., Gardner, E.W., 1929. Recent work on the problem of LakeMoeris. Geographical Journal 73, 20-60.

Caton-Thompson, G., Gardner, E.W., 1934. The Desert Faiyum. Royal Anthropological Institute. London, 167 pp.

Ehrenberg, C.G., 1845. Neue Untersuchungenüber das kleinste Leben als geologisches Moment. Bericht über die zur Bekanntmachung geeigneten.Verhandlungen der Königlich-Preussischen Akademie der Wissenschaften zu Berlin, 53-87.

El-Shabrawy, G.I., Daumont, H.J., 2009. The Faiyum depression and its lakes. Biomed. Life Sciences 89, 95-124.

El Wakeel, S.K., 1963. A study of the bottom deposits of Lake Qarun. Egypt Part I, Mechanical analysis. Bulletin of the Faculty of Science, Alexandria University 5, 33-60.

El-Sayed, E., Guindy, K.A., 1999. Hydrochemical investigations of El Faiyum locality with special reference to the sulphate enrichment phenomenon in Lake Qarun. Bulletin of the Faculty of Science of Mansoura University26, 1-21.

Embabi, N.S., 2004. The Geomorphology of Egypt, Landforms and Evolution. The Nile Valley and the Western Desert 1, Cairo.

Flower, R.J., Keatings, K., Hamdan, M., Hassan, F.A., Boyle, J.F., Yamada, K., Yasuda, Y. 2012. The structure and significance of early Holocene laminated lake sediments in the Faiyum Depression (Egypt) with special reference to diatoms. Diatom Research 27, 127-140.

Flower, R.J., Keatings, K., Hamdan, M.A., Hassan, F.A., 2013. Stephanodiscus. Species from Holocene sediments in the Faiyum Depression (Middle Egypt). Phytotaxa 127 (1), 66-80.

Flower, R.J., Stickley, C., Rose, N.L., Peglar, S., Fathi, A.A., Appleby, P.G., 2006. Environmental changes at the desert margin: an assessment of recent palaeolimnological records in Lake Qarun, Middle Egypt. Journal of Palaeolimnology 34, $1-24$.

Gasse, F., Fontes, J.C., Plaziat, J.C., Carbonel, P., Kaczmarska, I., De Deckker, P., Soulie-Marsche, I., Callot, Y., Dupeuble, P.A., 1987. Biological remains, geochemistry and stable isotopes for the reconstruction of environmental and hydrological changes in the Holocene lakes from North Sahara. Palaeogeography, Palaeoclimatology, Palaeoecology 60, 1-46.

Haynes, C.V., 2001. Geochronology and climate change of the Pleistocene - Holocene transition in the Darb el Arba in desert, eastern Sahara. Geoarchaeology 16 (1), 119-141.

Hakansson, H., Ehrlich, A., 1987. Stephanodiscus galileensis sp. nov. from Holocene subsurface sediments of Lake Kinneret, Israel. Diatom Research 2, 15-21.

Hassan, F., 1984. Mid-Holocene desertification and human responses in the Western Desert of Egypt. Paper presented at the $17^{\text {th }}$ Annual Charcoal Conference, Calgary.

Hassan, F., Hamdan, M., Flower, R., Tassie, G., 2011. Holocene geoarchaeology and water history of the Fayum, Egypt. In
Pirelli, R. (Ed.), Natural and Cultural Landscapes in the Faiyum, 116-133. UNESCO, Cairo.

Hassan, F.A., 1986. Holocene lakes and Prehistoric settlements of the western Faiyum. Journal of Archeological Science 13, 483-501.

Hassan, F.A., Barich, B., Mahmoud, M., Hemdan, M.A., 2001. Holocene playa deposits of Farafra Oasis, Egypt, and their palaeoclimatic and geoarchaeological signi cance. Geoarchaeology 16 (1), 29-46.

Hassan, F.A., Hamdan, M.A., 2008. The Faiyum Oasis - climate change and water management in ancient Egypt. InTraditional Water Techniques: Cultural heritage for a sustainable future, 117-147. 6th Framework Programme, Shaduf Project.

Hassan, F.A., Hamdan, M.A., Flower, R.J., Keatings, K., 2012. The oxygen and carbon isotopic records in Holocene freshwater mollusc shells from the Faiyum paleolakes, Egypt: Their paloenvironmental and paleoclimatic implications. Quaternary International 266, 175-187.

Hecky, R.E., Kling, H.J., 1987. Phytoplankton in the Great Lakes in the Western Rift Valley of Africa.Archiv fur Hydrobiologie Ergebnisse der Limnologie 25, 197-228.

Issawi, B., 1976. Geology of the Faiyum Depression. In: Wendorf, F., Schild, R. (Eds), Prehistory of the Nile Valley, 151-155. Academic Press, New York, San Francisco, London.

Keatings, K., Holmes, J.A., Flower, R.J. Horne, D., Whittiker, J.E., Abu-Zied, R.H., 2010. Ostracods and the Holocene palaeolimnology of Lake Qarun, with special reference to past human-environment interactions in the Faiyum (Egypt). Hydrobiologia 654, 155-176.

Kilham, P., 1971. A hypothesis concerning silica and the freshwater planktonic diatoms. Limnology and Oceanography 16, 10-18.

Kilham, P.,1990. Ecology of Melosira species in the Great Lakes of Africa. InTilzerM.M., Serruya, C. (Eds), Large Lakes Ecological Structure and Function, 414-427. Springer,Berlin.

Kilham, P., Kilham, S.S., Hecky, R.E., 1986. Hypothesized resource relationships among African planktonic diatoms. Limnology and Oceanography 31, 1169-1181.

Kindermann, K., Bubenzer, O., Nussbaum, S., Riemer, H., Darius, F., Pöllath, N., Smettan, U., 2006. Palaeoenvironment and Holocene land use of Djara, Westerndesert of Egypt. Quaternary Science Reviews 25, 1619-1637.

Kobusiewicz, M., 1976. Pradzieje północno-wschodniej Afryki między 16 a 5 tysiącleciem p.n.e. Przegląd Archeologiczny 24, 5-102 (in Polish).

Kozłowski, J.K., Ginter, B., 1993. Holocene change in the Faiyum; Lake Morris and the evolution of the Climate in Northeastern Africa. In: Krzyżaniak, L., Kobusiewicz, M. (Eds), Environmental change and human culture in the Nile Basin and northern Africa until the Second Millenium BC, 327-336. Poznań.

Kuper, R., Kröpelin, S., 2006. Climate-controlled Holocene occupation in the Sahara: motor of Africa's evolution. Science 313, 803-807.

McCorriston, J., 2006. Breaking the rain Barrier and the tropical spread of Near-eastern agriculture into southern Arabia. In: Kennett, D.J., Winterhalder, B. (Eds), Behavioral Ecology and the Transition to Agriculture, 217-236. University of California Press, Berkeley.

Mehringer Jr, P.J., Peterson, K.L., Hassan, F.A., 1979. A pollen records from Birket Qarun and the recent history of Faiyum. Quaternary Research 11, 238-256.

Phillips, R., Holdway, S., Wendrich, W., Cappers, R., 2012. Mid-Holocene occupation of Egypt and global climatic change. Quaternary International 251 (2012), 64-76.

Pilskaln, C.H., Johnson, T.C., 1991. Seasonal signals in Lake Malawi sediments. Limnology and Oceanography 36(3), 544557. 
Przybyłowska-Lange, W., 1976. Diatoms from the Site E71K14, Area 1, Trench 1, upper diatomaceous silt. In: Wendorf, F., Schild, R. (Eds), Prehistory of the Nile Valley, 321-323. Academic Press, New York.

Said, R., 1962. The geology of Egypt. Elsevier. Amsterdam, 377 pp.

Said, R., 1993. The River Nile: Geology, hydrology and utilization. Pergamon Press, Oxford.

Said, R., Albritton, C., Wendorf, F., Schild, R., Kobusiewicz, M., 1972a. A preliminary report on the Holocene geology and archaeology of the Northern Faiyum Desert. In: Reeves, C.C. (Ed.), Playa Lake Symposium, 41-61. Icassals Publication 4. Texas.

Said, R., Albritton, C., Wendorf, F., Schild, R., Kobusiewicz, M., 1972b. Remarks on the Holocene geology of Northern Faiyum Desert. Archaeologia Polona 13, 7-22.

Sandford, K.S., Arkell, W.J., 1929. Paleolithic man in the Nile Faiyum divide. University of Chicago Press. Oriental Institute, Chicago Publication 10, $68 \mathrm{pp}$.

Shirai, N., 2010. The archaeology of the rst farmer-herders in Egypt. Leiden University Press, Leiden.

Simonsen, R., 1979. The diatom system: ideas on phylogeny. Bacillaria 2, 9-71.

Stanley, D.J., McRea, J.E., Waldron, J.C., 1996. Nile Delta Drill Core and Sample Database for 1985 - 1994: Mediterranean Basin, (MEDIBA) Program. Smithsonian Institution Press, Washington D.C.

Soliman, G.F., 1990. Observations on some physical conditions of Lake Qarun. In: El-Raey, M. (Ed.), Regional symposium of en- vironmental studies, 588-601. UNARC. University of Alexandria, Egypt.

Talling, J.F., Sinada, F., Taha, O.E., Sobhy, E.M.H., 2009. Phytoplankton: composition, development and productivity. In: Dumont, H.J. (Ed.), The Nile, origin, environments, limnology and humanuse, 431-462. Monographiae Biologicae 89.

Tilman, D., Kilham, S.S., Kilham, P., 1982. Phytoplankton community ecology: Therole of limiting nutrients. Annual Review of Ecology and Systematics 13, 349-372.

Wendorf, F., Schild, R., 1976. The Prehistory of the Nile Valley. Academic Press, New York.

Wendorf, F., Schild, R., Close, A.E., 1986. The Wadi Kubbaniya Skeleton: A late Palaeolithic burial from southern Egypt. The Prehistory of Wadi Kubbaniya 1. Southern Methodist University Press, Dallas.

Woodward, J.C., Macklin, M.G., Krom, M.D., Williams, M.A.J., 2007. The Nile: evolution, Quaternary river environments and material fluxes. In: Gupta, A. (Ed.), Large Rivers: geomorphology and management, 262-292. Wiley \& Sons, London.

Yamada, K., Yasuda, Y., Shinozuka, Y., Yonenobu, H., 2011. Changes of sedimentological environments during the Holocene in Lake Qarun, Faiyum Basin, Egypt. Japan Geosciences Union Meeting, May 22-27th (Abstract). Japan Geosciences Union, Japan.

Zolitschka, B., Francus, P., Ojala, A.E.K., Schimmelmann, A., 2015. Varves in lake sediments, a review. Quaternary Science Reviews 117, 1-41. 